\title{
Emilio Lucio-Villegas \\ TOO MANY EVENINGS. LEARNING DEMOCRACY FROM A PARTICIPATORY BUDGET PROCESS
}

The problem with democracy, Oscar Wilde once wrote, is that it takes too many evenings (Biesta, De Bie, \& Wildemeersch, 2014, p. XIII).

\begin{abstract}
In this article, I reflect on experiences linking adult education to citizenship and participation. I consider citizenship to be connected to social justice and social inclusion. I suggest that a key element in citizenship is participating in public issues which concern life in communities in order to build an egalitarian relationship among people. In this article, I connect participation to a singular experience: the Participatory Budget Experiment in the city of Seville from 2003 to 2007. I explore specific experiences within adult education through participatory research and the elaboration of teaching materials addressed to this end. Finally, I reflect on the consequences of these experiences for an emancipatory adult education that aims to teach and learn democracy.
\end{abstract}

Keywords: adult education, citizenship, communities, democracy, participatory research

\section{PREVEČ VEČEROV. UČENJE DEMOKRACIJE NA PODLAGI PARTICIPATIVNEGA PRORAČUINSKEGA POSTOPKA - POVZETEK}

V članku se ukvarjam z izkušnjami, ki povezujejo izobraževanje odraslih z državljanstvom in participacijo. Državljanstvo je zame povezano s socialno pravičnostjo in družbeno vključenostjo. Predlagam, da je ključni element državljanstva sodelovanje pri javnih vprašanjih, povezanih z življenjem v skupnostih, $z$ namenom ustvarjanja egalitarnih odnosov med ljudmi. V članku obravnavam participacijo v povezavi s specifično izkušnjo: eksperimentom participatornega proračuna v mestu Sevilja med letoma 2003 in 2007. Prek participatorne raziskave in oblikovanih učnih gradiv raziskujem specifične izkušnje znotraj izobraževanja odraslih. Na koncu se ukvarjam s posledicami, ki jih te izkušnje imajo za emancipatorno izobraževanje odraslih, katerega cilj je poučevanje in učenje demokracije.

Ključne besede: izobraževanje odraslih, državljanstvo, skupnosti, demokracija, participatorna raziskava 


\section{INTRODUCTION}

What is citizenship? Who is a citizen? When democracy and participation appear to be threatened, the answers to these questions seem crucial. However, not everyone believes that these concerns are necessary for a person's development. In fact, documents regarding Lifelong Learning enacted by the European Union in recent years have moved from a clear commitment to active citizenship to focus only on the labour market (Lucio-Villegas, 2014). In the article I try to describe a programme connecting adult education and citizenship in the framework of the participatory budget experiment (hereafter PBE) in the city of Seville. To this end, I have selected three initiatives that are representative of specific ways of treating the issues related to citizenship from a community-based view of adult education.

The structure of the paper is as follows: first, I provide a theoretical framework with a focus on communities, democracy, participation, and citizenship. The section devoted to methodology starts from the institutional assignment. Then I focus on participatory research as a general approach to build a democratic proposal that includes researchers from both academia and the community. Findings and conclusions aim to contribute to the debate about the relationships between citizenship and democracy, and adult education. Finally, it is important to note that the experiences described in this article were funded by the Municipality of Seville. This is important not only in terms of recognising the funding but also because the institutional assignment was based on the idea of enabling adults to participate.

\section{LIVING IN COMMUNITIES: DEMOCRACY, PARTICIPATION, AND CITIZENSHIP}

According to Santos (1998), there are three common social contract oriented understandings of representative democracy: i) the social contract itself refers to individuals and their groups; ii) the concept of citizenship refers to a particular territory; the people living in this territory are citizens, whereas those outside of it (e.g., immigrants) are not citizens; and iii) the contract only holds for public issues; thus, the domestic realm is not part of the contract. Together, these three understandings constitute a specific worldview, one that is white, male, and involves people's control of nature.

Considering points ii) and iii), it is possible to think that there are people outside of this social contract. For instance, migrant people are 'in' and, at the same time, 'out' of the territory they live. On the other hand, there are spaces outside of this social contract, such as domestic spaces that hold relationships between men and women, parents and children, etc. It could be interesting here to note the difference that Torres (2005), following McPherson, established between formal democracy and substantive democracy. The former is characterised as political representation that includes voting, free elections, a parliament, and the supremacy of individual rights over collective ones. A substantive democracy involves a shift in people's relationships at both the micro and macro 
levels. It also includes people's participation in politics and egalitarian rights for every citizen. This model of participatory democracy is one of the foundations of the project. This seems to be a guarantee that democracy is beyond political rights and includes relationships among individuals, and an attempt to make health, education, social services, culture, etc., accessible for all in order to build a distributive democracy (Santos, 2003).

\section{ON COMMUNITIES}

I consider that privileged spaces where participatory democracy takes place are the communities people live in. In this sense, Wildemeersch and Vandenabeele (2007) describe community as a place in which conflict is the common issue. Pursuing this end, the authors follow Mouffe, who opposes 'politics' to 'the political'. The former refers to a consensual view of community that "is about creating consensus among different actors involved in the decision-making process, mainly by neglecting some of the basic conflicts" (Wildemeersch, 2014, p. 22). However, "the political", which is basically "dealing with conflicts", (ibid.) is associated with insecurity and risk. The world tends to be divided into 'them' and 'us' (Hoggart, 1965), whereby the 'us' creates a shelter against insecurities and 'the other' can be identified as the reason for these insecurities (Wildemeersch \& Vandenabeele, 2007, pp. 27-28). The other is always an individual that comes from outside the community: the immigrant, the different, etc. To react against this current hegemonic view, it is important to stress that differences, uncertainty, diverse culture and understandings could be the basis through which it is possible to recover participation and create a new awareness about communities as heterogeneous spaces. In this sense, it is important to remember that "reduce inequality, policies should be universal in principle, paying attention to the needs of disadvantaged and marginalized populations" (United Nations, n.d.) to build sustainable communities.

\section{ON PARTICIPATION AND CITIZENSHIP}

Gaventa (2006) distinguishes four stages in the evolution of participation. First, in the 1960s, the notion that communities could organise themselves to fight for their demands; Gaventa connects this period with Paulo Freire's seminal work, Pedagogy of the Oppressed (1970). Second, the expansion of NGOs in the 1980s overlapped with the concomitant growth in programmes related to water, health, agriculture, and other areas of risk to well-being. This era can also be associated with a new term: beneficiaries. Consequently, only some of the participants, but not the community as a whole, are involved. Third, during the 1990s, the scope of participation was made even narrower with the introduction of another new term: stakeholder. According to Gaventa (2006), this ambiguous word represents the abandonment of community itself. Stakeholders are presented as "representatives of civil society's private sector, government, and donors, but not necessarily with any view as to whether they indeed represented the poor or excluded within these sectors" (Gaventa, 2006, p. 56, italic type in the original). Finally, by the late 1990s, there was a return to participation focused on exercising the rights of citizenship. In this 
approach, citizenship was understood as a practice and an engagement rather than as something defined by law. As Wildemeersch (2014) states, citizenship is not simply about the exertion of rights but also about actively engaging in practices and decision-making processes.

Citizenship can also be considered a set of relationships between people (Heller, \& Thomas Isaac, 2003). Ideally, this relationship would be constructed in an egalitarian manner. However, citizenship is subverted by social differences (e.g., class, gender, ethnicity, etc.). In any sense, citizenship is an exclusive concept that introduces differences among people: landlords and slaves; men, women and children; native and foreigner, and others. One is a citizen thanks to other people that are not. Both participation and citizenship must help to build a redistributive democracy to avoid the exclusion of people, as Santos (2003) states. This concept of redistributive democracy is very present in the process of participatory budgeting.

Participation, thus, becomes a strategic element for accomplishing citizenship, but participation can also be hijacked: "Who speaks on behalf of whom? Who sets the framework for participation? Who creates boundaries and dismantles them?" asked Mohanty and Tandon (2006, p. 15). Managing these questions and answers is not only important for the acquisition of citizenship but also for the maintenance of citizenship.

\section{THE PARTICIPATORY BUDGET}

I refer to the participatory budget as a means of organising democracy in a specific way: as deliberative and participatory democracy. The background of the participatory budget offers material for a diverse analysis based on politics, participation, and descriptions of both methodologies and experiences (e.g., Avritzer, 2003; Lucio-Villegas, 2015; Santos, 2003).

The most well-known and important participatory budget process was in Porto Alegre, Brazil (Melgar, 2014). Following this was a vast catalogue of experiences ranging from decision-making at different levels to consultation processes. Therefore, it is important to remember that a participatory budget involves decision-making by citizens. Santos (2003) stressed that one of the main elements that characterised the Participatory Budget in Porto Alegre was the power to decide.

The main aim of the participatory budget is to encourage actions and establish a sustainable mechanism of shared management about public resources through collective decisions regarding the distribution of the budget (Santos, 2003, p. 389).

With regard to educational outcomes, one interesting work is the analysis performed by Lerner and Schugurensky (2007) on the participatory budget in Rosario, Argentina. According to the authors, it is possible to differentiate four assets that led to learning 
and changes in people's participation (pp. 92-95): first, increased knowledge relates to a greater awareness of one's rights as citizens; second, changes in skills address ways to "monitor governments' actions, contact government agencies and officials" (p. 93); third, changes in attitudes translate to increased self-confidence; and lastly, changes in practices lead people to become more committed to community life.

Lerner and Schugurensky (2007) also present several "Indicators of Learning and Change" (pp. 91-92) and divide them into four areas: knowledge (e.g., about city government), skills (e.g., speaking in public with clarity), attitudes (e.g., self-confidence), and practice (e.g., interest in community participation). They also stress the following:

The capacity to listen, a precondition for deliberative democracy, is usually taken for granted. However, participants do not always have the necessary listening skills for a fruitful dialogue, and many develop these competences through the process (p. 94).

Lerner and Schugurensky (2007) attempted to delimit the changes derived from the process of participation:

In general, the initial inequalities between demographic groups disappeared through involvement in the participatory budget. Because people with low initial indicator levels learned and changed more, they tended to end up with the same extent of citizenship knowledge, skills, values, and behaviours as those with high initial levels (p. 97).

In our case, disparities in the quality of and the access to participation were very present and depend on the institutional assignment, as will be explained later on in the section devoted to methodology.

\section{The Participatory Budget Experiment in the city of Seville}

When Seville, following the model of Porto Alegre (Brazil), launched the PBE, its main aim was to generate an open citizen space to debate and make decisions. If I refer to the process as an experiment this is because in the agreement between the Spanish Socialist Party (PSOE) and the United Left (Izquierda Unida, IU) they concurred to develop a process of participatory budgeting in an experimental way that would have to be evaluated at the end of the municipal term of office.

The basic structure for participation adopted was the District Assembly. This is a binding process in which the decisions that were made were incorporated into the Municipality's budget with corresponding citizen, technical, and political co-responsibility. The participatory budgeting system followed a timeline that began approximately eight months before the approval of the municipal budget (around the month of December), when neighbourhood assemblies were convened in which technicians from the Municipality reported on available resources in the areas that had been identified for the implementation of this 
system. It is important to clarify that there were some issues for which it was not possible to make decisions, such as the salaries of civil servants and other workers of the Municipality, or taxes.

To make the process flexible, the city was divided into 21 zones according to the existing districts, and community centres were converted into spaces of participation and encounter. In each of these districts, so-called neighbourhood motor groups improved the dynamics of the community to maintain citizenship information and helped with the organisation and channelling of neighbourhood proposals to the assemblies. Among these proceedings, the call for and development of the district assemblies was the most important action, as it involved the distinctive structure of the participatory budget and was involved in the overall fundamental aspects of the process, including configuring the basis for direct participation.

\section{METHODOLOGICAL APPROACH}

In this section I shall present the institutional assignment. It is very important in terms of clarifying to the reader the reason for selecting some initiatives and not others to explain the case. After this I will discuss participatory research, and finally I will present an explanation of the sources of the data presented.

\section{Institutional assignment}

In the PBE in Seville, one of the main problems that people faced was difficulties in understanding how to participate in direct democracy. According to some unpublished data from the Municipality, half of the population of the city was functionally illiterate. Functional illiteracy refers here to people with difficulties in using basic literacy tools to communicate and understand the surrounding world. In this specific case this refers to individuals with problems in understanding the rules about participation in the assemblies, and people who would have problems filling out the form for presenting proposals, etc. Thus, people - as individuals or as a group - had to submit written proposals in a specific form. The proposal had to be summarised in around 100 words along with other information about the proponent, the relevance of the proposal, etc. Then, the proposal had to be discussed in an assembly, which meant that the proponent had to give an oral performance of 5 to 10 minutes. After the proposal was approved, it went to municipal technicians and the proponent had to discuss with them the implementation of it. Finally, there were assemblies to evaluate procedures and the measures to be taken.

Moreover, people had to know how to navigate through this process in an autonomous way: how to fill out the form; how to organise an oral presentation and focus on the most important things that they wanted to communicate; how to manage the project in both economic and administrative terms; etc. Thus, there was a danger that they would be excluded from the decision-making processes. The Municipality decided to confront this problem with an adult education program that was developed from November 2005 to 
December 2007 to improve the quality of participation by improving education for participation. An important part of this institutional assignment was the elaboration of a set of teaching materials that I shall briefly describe below.

The main goal was the facilitation and promotion of citizen participation through the analysis and knowledge of people's daily realities. The material was divided into three sections: Me and my environment, concerning the analysis of the surrounding reality; Something more than a word, to reflect on participation and democracy; and The participatory budget, to focus on how to develop and present proposals to the assemblies. The teaching material was also divided into 10 activities. Each activity included the number and title, the main goal, the specific objectives, the development, the material resources needed, the multidisciplinary tools necessary to facilitate the understanding of the activity, annexes and work sheets for the students. Furthermore, the material included an evaluation for teachers and adult learners. All the teaching material is available online ${ }^{1}$.

Another set of tasks to generate a response to the institutional assignment was to mobilize help and support to organise activities in certain communities: a group of tenants that had occupied a block of social housing, a group of women organising a theatre workshop, another group of women demanding an elevator for their adult education school, or people researching their own stories within the framework of the history of the country, and a set of courses addressed to people in social movements, amongst others.

I have selected three experiences to look at in greater detail further below. The first one is related to gentrification processes in a historic district of the city. This group consisted of 25 people, mainly women, with the age range of 55 to 80 . In the second group, which was related to the recovery of the collective memory of people attending an adult education school, the research team was led by adult learners who gathered knowledge about their own experience. This group was made up of a coordinator (a teacher) and 8 adult learners, five female and three male adult learners. Finally, the third initiative described below, the Participatory and Citizenship School, addressed the lack of democracy and participation inside social movements.

\section{Participatory research as methodology}

Participatory Research (hereafter PR) can be considered an adequate methodology for undertaking these initiatives. First, PR is a methodology that deepens democracy and the construction of knowledge. Second, it stems from problems and concerns which people face in their daily life and enables them to develop their experiences and ways to change their reality.

Regardless of the starting conditions, nevertheless, a sense of participation needs to be regained. It is impossible to develop a practice of PR without participation. At a conference in Cartagena de Indias, Colombia, in 1997, Fals advocated the use of PR as opposed

1 See: https://www.researchgate.net/publication/284730159_Educando_para_la_ciudadania_desde_por_y_ para_la_participacion. 
to Action-Research (or Participatory Action Research), emphasising participation as the essence of this methodology (Fals, 1998). According to Hall (2001), PR can be used as "a descriptive term for a collection of varied approaches which share a participatory ethos" (p. 173, italic type in the original). Fals (2001) used the Spanish term vivencia to refer to "a complex of attitudes and values that would give meaning to our praxis in the field" (p. 31). He added:

With the careful human touch of vivencia and its needs for symmetry in social relations, it becomes easy to listen to discourses coming from diverse intellectual origins or conceived with a different syntax (p. 31, italic type in the original).

In short, as defined by Fals, vivencia calls upon us to develop dialogue as a necessary tool for building knowledge that will transform reality in an educational way.

\section{Sources of data}

Evidence presented in the findings derives from diverse research tools and sources. The main source of data was the field notes of the researchers working with the different groups of people (cited in the article as $f n 1, f n 2$ and $f n 3$ ). There are writing materials produced by the participants in order to describe and reflect on their situation which were published by the project (García \& Lucio-Villegas, 2009). These short texts are a very powerful source of information because they are the voices of people that were not replaced by researchers. In two different adult education schools the teaching material was tested. Finally, the Participatory and Citizenship School was evaluated by the participants through a limited survey. The results of the questionnaires were analysed using descriptive statistics (cited in the text as $Q R$ ). Ultimately, another source of data and information are the annual reports presented to the Municipality that summarised the development of the project. They are cited in the text as CHR 2006 and CHR 2007.

\section{DESCRIPTION OF THE CASES}

To describe the relationships between adult education and citizenship in the framework of the specific case of the participatory budget experiment in the city of Seville, I will briefly describe each of them in turn.

\section{Tenants against gentrification}

At least since 1992, historical neighbourhoods in Seville have suffered from a process of gentrification. In this specific case, the process occurred in a neighbourhood called $S B$ with a strategic location for the expansion of the city to the east. As is typical of some old buildings, the owner neglected the building's care and maintenance and sought the Municipality's condemnation of the ruined edifice and the consequent eviction of the tenants. This situation caused damage to the building and worsened the quality of life for 
the people living there. Some of these buildings were of a traditional type of construction called Patio de Vecinos that derived from the subdivision of

a house into many rooms and each room was rented independently [...]. The occupants, therefore, had only one room for all of the family and a shared kitchen, toilet, courtyard and access to water (Lucio-Villegas, García, \& Cowe, 2016, p. 88).

After 15 years of protests and efforts to claim their right to their homes, some neighbours in SB decided to move into and occupy an empty block of social housing which was the property of the Municipality. In this case, work with these people was focused on daily tasks, such as understanding documents from the Municipality, writing their own documents, strengthening social networks, recovering the history of their neighbourhood, and discovering the existence of an identity between space and people. This was an emancipatory process to guarantee that their voice was heard. In reflecting about their situation, they wrote,

How is it possible that people who never neglected their obligations as tenants have to demand that public authorities require the owners to fulfil their duties? We question this abandonment by the Municipality and maintain the existence of a real and effective right to have a house (García \& Lucio-Villegas, 2009, p. 33).

\section{Recovering Memories (Historic Memory Workshop - HMW)}

This initiative is related to the collection of both individual and social stories related to the Civil War and the Dictatorship (1936-1975). It was an attempt to help people to recover their own memories and to connect them with history. These memories focused on the period corresponding to the $2^{\text {nd }}$ Republic, the Spanish Civil War, the post-war years, and the Dictatorship. It is important to highlight that some of the members of the workshop also participated as informants, which further enriched the experience.

Thirty life histories were recorded, and more than 20 were written, initiating the analysis, systematisation and elaboration of this material. Three centres of interest were defined for this historical period during the process of analysis: repression, work and education. However, the participants wrote:

Our project doesn't end here; this is only the beginning. We want to keep working with the remaining interviews to help hear the voices of the people that in the past and still now are silenced (García \& Lucio-Villegas, 2009, p. 28).

Currently, a second book of new memories and people's histories has been published (Taller para la Recuperación de la Memoria Histórica, 2016) with a focus on the time of the restoration of democracy, trade unions and political parties in the country. 


\section{The Participatory and Citizenship School (PCS)}

The PCS during the time of the PBE was planned and organised through 14 courses that amounted to 24 hours each (the original idea was for a 40-hour course) for two weeks from Monday to Thursday, usually in the evening. The courses focused on participation, conflicts, mediation skills, community analysis, and the development of a community project. Every course was divided into four components: (1) how to define community problems; (2) a reflection on democracy and citizenship at both a macro (community) and micro (association) level; (3) how to design and develop a project; and (4) how to look for and manage resources. Courses took place in community centres located in different districts around the city. The average number of people who attended the courses was 12 , usually women with an average age of 50 who were participating in an association or attending a post-literacy level course in adult education schools. An initial prerequisite was that the participants had no previous roles in leading association groups. Another important aspect of each course was that people coming from participating associations were heterogeneous. For instance, one course included: a flamenco association, a fishing club, an immigrant workers' association, a neighbours' association, the market owners' association, a motorcycle club, an association of mothers and fathers at the primary school, and a cyclists' group.

\section{FINDINGS}

I present the findings, focusing on two aspects. On the one hand, I will try to describe the basic literacy tools needed for participation. On the other, I will focus on participatory research - and vivencia as a part of it - as a methodology valuable for implementing citizenship.

\section{Basic literacy tools needed to participate}

Basic literacy tools seem to be essential for building and strengthening democracy and citizenship (Santos, 2003). One of the responses that the research team tried to provide was the development of teaching material which connected learning to participation and democracy in the context of adult education. This teaching material starts from a number of generative words (Freire, 1965) and was an attempt to organise learning processes. For instance, one of the activities suggested was the creation of a household budget that people could implement in their homes in order to demonstrate that a budget is basically a process that examines revenues and prioritises expenses.

An important point of these literacy tools is connected to the development of oral skills. As Lerner and Schugurensky (2007) stated, it appears important to develop public speaking and the capacity for listening. The teaching material includes activities about how to build one's own history, how to organise it, and how to present it to a group in a public assembly. The main idea is that individuals can develop performative skills to present and debate their own ideas in the public arena.

In my view, a process of participatory democracy involves three different moments: dialogue and public debate, decision-making, and actions. In the case of the PBE, these three 
moments are organised around social movements. In this scenario, it is important to realise that social movements are - in the tradition of the country - traditionally connected to political parties that in many cases have co-opted some individuals and have, to some extent, left social movements without leaders. Nevertheless, as Tsuchiya (2007) states, it is important to "constantly scrutinise their practice [i.e. that of the social movements] in a democratic light" (p. 82). We cannot take for granted that social movements function democratically by themselves. In fact, in the PCS, only the course addressed to the Roma women's association guaranteed that the participants were individuals who were not involved in any position of that association (CMR, 2007).

The evaluation of the courses seems to show that the pace of the people differs from that of the educators. People expressed that they felt stressed because the time devoted to some sections of the course did not allow sufficient time to reach a deeper understanding of other elements. When the courses were evaluated, some problems were highlighted: the use of communicative tools, of mediation skills, and acquiring knowledge about how to manage a project and the use of a dialogical methodology $(\mathrm{QR})$. Another issue is related to the opportunity to establish relationships with other associations and individuals in the neighbourhood. This is in line with Lerner and Schugurensky's (2007) research that stressed the importance of people knowing others from different groups or neighbourhoods. In our case, the diversity of people - as mentioned above - attending courses could ensure the creation of new bonds among individuals.

Finally, this knowledge allows individuals to become more committed to community life. In this direction, one of the findings of the PCS was that people found that courses were very useful for gaining a better knowledge of their own community (QR). After the relative failure of the PCS, two issues arose. The first is the importance of initiatives that come from the ground and from common people in their own communities. The second is the importance of the collective. Participatory research and vivencia can provide a response to these matters.

\section{Participatory research and vivencia}

An important feature of two of the subcases described - the tenants' organisation and the research into memory and life histories - is the self-organised process that emerges from the people rather than from the educators or the city authorities. The tenants in SB, for example, decided to band together as a collective to claim their rights. The response from the municipal authorities was the threat of eviction from the building and an individual approach by the municipal social services. Thus, the objective of the Municipality was to individualise the struggle. The tenants decided to join together to resist the eviction and the individualisation of the problem (fn1). They decided to conjugate the "dangerous pronoun" (Sennett, 2000, p. 143) and learn how to become 'we' rather than ' $\mathrm{I}$ '.

In the HMW project, people were able to recover their own history and to recover their memories. This ability came from their desire and their curiosity to learn about the history 
of the country and their own role in this history. The 'success' of this experience has its foundations in people's interest and attempts to fulfil their desire to know about their own life by explaining the present from the past - a silenced past about which people told tales and stories.

Participatory research seems to be an appropriate methodology for undertaking these types of processes which look for emancipation (Inglis, 1997). In each of the experiences described, the starting point was real situations that people face in their community. As one of the participants in the PCS affirmed in a meeting with educators: "Who else can better analyse reality than those who live daily within it?" (fn2). The concept of vivencia discussed by Fals (2001) is clearly present in this statement. In the case of the HMW project, participatory research is also enriched by another element: the return of the research to the community, either by publications or public sessions, to explain the research process and the findings in a democratic research practice (fn3).

Educators involved in the project tried to encourage people to participate in every moment of the process, but also by joining people in their own process of participation. This is very clear in the case of the Historic Memory Workshop. The major task here was to give support to a process organised by the adult learners themselves (fn2). In this case, vivencia can be considered a process of creating bonds and respect, and supporting the process of reflection, action and creation of knowledge undertaken by people. On the other hand, educators helped people by creating knowledge to become more conscious of their rights. For instance, the tenants in SB think as a result about their duties, but also about the duties of the owners of the building and about the duties of a democratic government (fn1).

\section{CONCLUSIONS}

I have noted in this article that people initially had difficulties in understanding the rules of participation. Education is not only a significant means of overcoming these difficulties but also of educating individuals about the processes related to the exercising of their rights. The experiences described were an attempt to both encourage and support individuals and groups traditionally excluded from public matters. People can present and debate their ideas and proposals as they did in the participatory budget assemblies and in other places, assuming that democracy involves claiming their rights (Wildemeersch, 2014).

Moving from common sense to good sense, in Gramscian terms, means, among other things, that people grasp and use research tools (see, for instance, Manacorda, 1976, pp. 238-244) which enable individuals to go from folklore to knowledge. What is this knowledge created by people? One manifestation of this knowledge is to monitor government. In the case of the PBE in Seville, every neighbourhood held an annual assembly to evaluate the implementation of the proposals approved in the previous assembly. In this way, they could ensure that the Municipality implemented the proposals approved in the assembly.

If a political project is also an educational one, as Gramsci affirmed (Mayo, 2007), two more issues have to be presented. On the one hand, the way to organise these proposals 
can only be related to a form of direct participation that guarantees the presence of people in every moment of the process. This is only possible by developing a substantive participatory democracy where the voice of the people is not mediated, and it is expressed directly to others, creating an open space for debate. Formal democracy, in the form of representation by voting for a few representatives every four years, doesn't guarantee the creation of this deliberative and participatory space.

On the other hand, a short response can be provided to the question: why is adult education a suitable tool for tackling these matters? Adult education is about more than preparing for the labour market. Adult education means, among other things, that people can analyse and change their surrounding reality. In Freire's words, individuals become conscious of their situation by taking part in social practices, invariably with other people (Freire, 1970). At a time when populist and neo-fascist leaders are arising thanks to simple speeches and manipulative messages, it seems important to encourage people to strengthen autonomous thinking in order to confront these speeches and deepen democracy.

At the end of the day, if participation, as Dewey ([1916] 1995) affirmed, can only be taught when people are participating, it is also true that being educated to participate emancipates people from the limitations that illiteracy and an incomplete education present in creating a true democracy.

\section{REFERENCES}

Avritzer, L. (2003). Modelos de deliberação democrática: uma análise do orçamento participativo no Brasil. In B. S. Santos (Ed.), Democratizar a democracia. Os caminhos da democracia participativa (pp. 467-496). Porto: Afrontamento.

Biesta, G. (2014). Learning in Public Places: Civic Learning for the Twenty-First Century. In G. Biesta, M. De Bie, \& D. Wildemeersch (Eds.), Civic Learning, Democratic Citizenship and the Public Sphere (pp. 1-11). Dordrecht: Springer.

Biesta, G., De Bie, M., \& Wildemeersch, D. (Eds.) (2014). Civic Learning, Democratic Citizenship and the Public Sphere. Dordrecht: Springer.

Clovis, J. (2007). Reconversão Cultural da Escola. Mercoescola e escola cidadã. Porto Alegre: Universidade Metodista.

Dewey, J. ([1916] 1995). Democracia y Educación. Madrid: Morata.

Fals, O. (1998). Experiencias teórico-prácticas. In O. Fals (Ed.), Participación popular: retos del futuro (pp. 169-236). Bogotá: ICFES.

Fals, O. (2001). Participatory (Action) Research in Social Theory: Origins and Challenges. In P. Reason, \& H. Bradbury (Eds.), Handbook of Action Research (pp. 27-37). London: Sage.

Freire, P. (1965). Educação como prática da liberdade. São Paulo: Paz e Terra.

Freire, P. (1970). Pedagogy of the Oppressed. New York: Continuum.

García, D., \& Lucio-Villegas, E. (Eds.) (2009). Participar participando. Estrategias participativas y educación de personas adultas. Sevilla: Publicaciones de la Cátedra Paulo Freire de la Universidad de Sevilla.

Gaventa, J. (2006). Perspectives on Participation and Citizenship. In R. Mohanty, \& R. Tandon (Eds.), Participatory Citizenship. Identity, Exclusion, Inclusion (pp. 51-67). New Delhi: Sage. 
Hall, B. (2001). I wish this were a poem of practices of Participatory Research. In P. Reason, \& H. Bradbury (Eds.), Handbook of Action Research (pp. 171-178). London: Sage.

Heller, P., \& Thomas Isaac, T. M. (2003). O perfil político e institucional da democracia participativa: lições de Kerala, India. In B. Sousa Santos (Ed.), Democratizar a democracia. Os caminhos da democracia participativa (pp. 497-535). Porto: Afrontamiento.

Hoggart, R. (1965). The Uses of Literacy. London: Pelican.

Inglis, T. (1997). Empowerment and Emancipation. Adult Education Quarterly, 48(1), 3-18.

Lerner, J., \& Schugurensky, D. (2007). Who learns what in Participatory Democracy? In R. van der Veen, D. Wildemeersch, J. Youngblood, \& V. Marsick (Eds.), Democratic Practices as Learning Opportunities (pp. 85-100). Rotterdam: Sense.

Lucio-Villegas, E. (2014). Basic skills for becoming citizen. In G. K. Zarifis, \& M. Gravani, (Eds.), Challenging the 'European Area of Lifelong Learning': A critical response (pp. 41-50). Dordrecht: Springer.

Lucio-Villegas, E. (2015). Adult Education in Communities. Approaches from a Participatory Perspective. Rotterdam: Sense.

Lucio-Villegas, E., García, D., \& Cowe, L. (2016). The city, the people, the home: A case study on education and citizenship in Spain. Studies in the Education of Adults, 48(1), 83-95.

Manacorda, M. A. (1976). La Alternativa Pedagógica. Barcelona: Nova Terra.

Mayo, P. (2007). Freire, Gramsci y la formación de personas adultas. Xàtiva: Edicions del CREC.

Melgar, T. (2014). A Time of Closure? Participatory Budgeting in Porto Alegre, Brazil, after the Workers' Party Era. Journal of Latin American Studies, 46(1), 121-149.

Mohanty, R., \& Tandon, R. (2006). Introduction. Identity, exclusion, inclusion: Issues in Participatory Citizenship. In R. Mohanty, \& R. Tandon (Eds.), Participatory Citizenship. Identity, Exclusion, Inclusion (pp. 9-26). New Delhi: Sage.

Santos, B. S. (1998). Reinventar a Democracia. Lisboa: Fundação Mário Soares/Gradiva Publicações.

Santos, B. S. (2003). Orçamento Participativo em Porto Alegre: para uma democracia redistributiva. In B. Sousa Santos (Ed.), Democratizar a democracia. Os caminhos da democracia participativa (pp. 375-465). Porto: Afrontamiento.

Sennett, R. (2000). La corrosión del carácter. Madrid: Anagrama.

Sennett, R. (2003). El respeto. Madrid: Anagrama.

Taller para la recuperación de la memoria histórica. (2016). La Memoria recuperada. La construcción de nuestros barrios a través de la lucha obrera y vecinal. Sevilla: Centro de educación de personas adultas 'Manolo Reyes'.

Torres, C. A. (2005). Democracia. In E. Lucio-Villegas, \& P. Aparicio (Eds.), Educación, democracia y emancipación (pp. 31-55). Barcelona: Diálogos.

Tsuchiya, K. (2007). Learning opportunities for active members of nonprofit organizations in Japan. In R. van der Veen, D. Wildemeersch, J. Youngblood, \& V. Marsick (Eds.), Democratic Practices as Learning Opportunities (pp. 73-84). Rotterdam: Sense.

United Nations. (n.d.). Goal 10: Reduce inequality within and among countries. Retrieved from: https:// www.un.org/sustainabledevelopment/inequality/.

Wildemeersch, D. (2014). Displacing Concepts of Social Learning and Democratic Citizenship. In G. Biesta, M. De Bie, \& D. Wildemeersch (Eds.), Civic Learning, Democratic Citizenship and the Public Sphere (pp. 15-28). Dordrecht: Springer.

Wildemeersch, D., \& Vandenabeele, J. (2007). Relocating social learning as a democratic practice. In R. Van der Veen, D. Wildemeersch, J. Youngblood, \& V. Marsick (Eds.), Democratic Practices as Learning Opportunities (pp. 19-32). Rotterdam: Sense. 